\title{
Aplikasi Pengarsipan Surat Masuk dan Surat Keluar Berbasis Web pada SMP Negeri 32 Pekanbaru
}

\author{
Yulisman ${ }^{1}$, Refni Wahyuni², Yuda Irawan ${ }^{3}$ \\ ${ }^{1,3}$ Program Studi Sistem Informasi, STMIK Hang Tuah Pekanbaru \\ ${ }^{2}$ Program Studi Teknik Informatika, STMIK Hang Tuah Pekanbaru \\ Jl. Mustafa Sari No. 5 Tangkerang Selatan, Pekanbaru, Riau, Indonesia \\ e-mail: yulismanaziera27@gmail.com¹, refniabid@gmail.com², yudairawan89@gmail.com³
}

Submitted Date: October $11^{\text {th }}, 2020$

Revised Date: November $03^{\text {rd }}, 2020$
Reviewed Date: October $26^{\text {th }}, 2020$

Accepted Date: November 04 $4^{\text {th }}, 2020$

\begin{abstract}
Archiving incoming and outgoing mail is very important in an organization, especially for institutions such as SMP Negeri 32 Pekanbaru. The filing of letters at SMP Negeri 32 Pekanbaru is still done by writing incoming and outgoing letters on the agenda book and storing letters in filing cabinets, making it difficult to find old letter archives and often losing letters. The purpose of this research is to find the right solution so that the archiving of incoming and outgoing mail at SMP Negeri 32 Pekanbaru is more effective and efficient by making an application for archiving incoming and outgoing mail. The method used in this research is the system development model method, namely the Waterfall Model. The application design and analysis model uses the UML (Unified Modeling Language) model which is an object-oriented language or OOP (Object Oriented Programming). Application development and development uses a static programming language, namely PHP (Hypertext Pre-processor) and MySQL as application database. The results of the research on the making of incoming and outgoing mail archiving applications are very helpful and easier for SMP Negeri 32 Pekanbaru in filing incoming and outgoing mail, especially the Administration (School Administration) section because letter archiving is already stored in the database. The conclusion is that the application is very easy and helpful in archiving incoming mail and this letter is evident from the user's assessment of the application with a value of $92 \%$ more effective and efficient.
\end{abstract}

Keywords: Archiving Applications; Incoming Mail; Outgoing Mail; Web; MySQL; PHP

\begin{abstract}
Abstrak
Pengarsipan Surat Masuk dan Surat keluar merupakan suatu hal yang sangat penting di suatu organisasi, terutama bagi institusi seperti SMP Negeri 32 Pekanbaru. Pengarsipan surat pada SMP Negeri 32 Pekanbaru masih dilakukan dengan menulis surat masuk dan keluar pada buku agenda dan menyimpan surat di lemari pengarsipan, sehingga menyulitkan dalam pencarian arsip surat yang lama dan sering terjadi kehilangan surat. Tujuan dari penelitian ini untuk mencari solusi yang tepat agar pengarsipan surat masuk dan keluar pada SMP Negeri 32 Pekanbaru lebih efektif dan efesien dengan membuat sebuah aplikasi pengarsipan surat masuk dan keluar. Metode yang digunakan dalam penelitian ini adalah metode model pengembangan sistem yakni Model Waterfall. Model perancangan dan analisis aplikasi mengunakan model UML (Unified Modeling Language) yang merupakan sebuah bahasa yang berorientasi pada objek atau OOP (Object Oriented Programming). Pembuatan dan pengembangan aplikasi menggunakan menggunakan bahasa pemrograman yang statis yaitu PHP (Hypertext Pre-processor) dan MySQL sebagai basis data aplikasi. Hasil dari penelitian pembuatan aplikasi pengarsipan surat masuk dan keluar ini sangat membantu dan mempermudah SMP Negeri 32 Pekanbaru dalam pengarsipan surat masuk dan keluar, terutama bagian Tata Usaha (Administrasi Sekolah) karena pengarsipan surat sudah tersimpan di basis data. Kesimpulan diperoleh bahwa aplikasi sangat mempermudah dan membantu dalam pengarsipan surat masuk dan surat ini terbukti dari penilaian pengguna terhadap aplikasi dengan nilai $92 \%$ lebih efektif dan efesien.
\end{abstract}

Kata Kunci: Aplikasi Pengarsipan; Surat Masuk; Surat Keluar; Web; MySQL; PHP 


\section{Pendahuluan}

Administrasi di sebuah instansi atau lembaga tidak lepas dari pengarsipan surat atau administrasi surat, seperti surat masuk dan surat keluar. Administrasi pengarsipan dan pengelolaan surat merupakan aktifitas yang sangat penting, karena dengan pengelolan surat yang baik dapat menjaga keutuhan informasi dari sebuah atau selembar surat, biarpun informasi tersebut tidak begitu berguna ketika surat diterima oleh instansi/lembaga/organisasi, namun dengan pengelolaan surat yang baik, maka informasi yang tesedia diselembar surat akan tersimpan dengan baik dan tentunya akan bermanfaat suatu saat nanti, ketika informasi yang tersedia pada surat dapat mendukung aktifitas perkantoran, karena surat bisa memberikan informasi lebih baik yang berhubungan dari luar dan dalam instansi/ lembaga/organisasi, dan oleh karena itu administrasi atau pengarsipan surat wajib dilakukan agar surat tetap terjaga, tidak hanya secara fisik dari surat tersebut juga informasi yang ada pada surat tersebut. Surat merupakan suatu alat yang digunakan sebagai media peghubung yang vital untuk berhubungan dengan pihak diluar isntitusi/lembaga maupun di dalam institusi/lembaga (Sharipuddin and Yani, 2018). Pengelolaan dan pengarsipan surat terdiri dari dua jenis surat, yaitu Pengelolaan dan pengarsipan surat masuk dan keluar. Adapun penjelasan Surat Masuk adalah seluruh surat yang masuk yang berasal dari instansi/lembaga/organisasi maupun dari individu yang diterima dan dikirim mamakai jasa pengiriman surat (Prawono and Pamungkas, 2015). Surat masuk juga dapat berasal dari pihak internal instansi/lembaga itu sendiri. Selanjutnya penjelasan dari Surat Keluar adalah surat yang dilengkapi oleh unsur-unsur utama dari surat, seperti surat telah bernomor, bertanggal, berprihal, nama penerima surat, berstempel, dan sudah disetujui dengan bukti adanya tanda tangan dari pimpinan atau pihak yang berhak yang dibuat oleh instansi/lembaga/organisasi yang dikhususkan kepada instansi/lembaga/organisasi lain atau perorangan dengan maksud memberikan informasi/permintaan /instruksi kepada pihak penerima surat (Masykur and Atmaja, 2015).

Pengarsipan dan pengelolaan surat masuk dan keluar ini sangat penting dilakukan terutama pada institusi pendidikan. SMP Negeri 32 Kota Pekanbaru merupakan sebuah instansi pendidikan yang ada Kota Pekanbaru dengan jenjang pendidikan menengah pertama. SMP Negeri 32 Kota Pekanbaru dalam aktivitas perkantoran, terutama dalam proses pembelajaran tidak terlepas dari administrasi pengarsipan dan pengelolaan surat. Administrasi pengarsipan dan pengelolaan surat di SMPN 32 Kota Pekanbaru masih dilakukan dengan menulis surat masuk dan keluar pada buku agenda sementara arsip surat secara fisik hanya disimpan ke dalam map dan lemari arsip, baik untuk arsip surat masuk maupun surat keluar. Proses pengarsipan dan pengelolaan surat masuk dan keluar tersebut terus berlangsung, setiap ada surat masuk dan surat keluar, untuk surat masuk dimulai pertama kali surat diterima oleh bagian Tata Usaha SMP Negeri 32 Pekanbaru untuk diteruskan ke Kepala Sekolah, kemudian di disposisikan sesuai isi surat tersebut. Untuk surat keluar bagian Tata Usaha mencetak surat keluar dengan dua rangkap, satu rangkap untuk dikirim dan satu rakap lagi untuk diarsipkan.

Proses administrasi pengarsipan dan pengelolaan surat masuk dan keluar pada SMP Negeri 32 Pekanbaru dengan cara di atas menimbulkan beberapa masalah, seperti sulitnya mencari arsip surat masuk atau keluar jika sewaktuwaktu kita membutuhkan informasi yang ada disurat tersebut dan ini akan membutuhkan waktu yang lama untuk menemukan selembar surat ditumpukkan arsip surat masuk dan kelaur yang begitu banyak, bahkan dapat memungkinkan hilangnya arsip surat masuk dan keluar atau mengalami kerusakan karena tidak tersimpan dengan baik. Permasalahan yang lainnya dalam administrasi pengarsipan dan pengelolaan surat pada SMP Negeri 32 Pekanbaru mengenai persentase surat masuk dan surat keluar cukup banyak dan tidak semua surat tercatat di buku agenda. Persentase penerimaan surat masuk dalam satu bulan 10-15 buah surat yang diterima bagian tata usaha SMP Negeri 32 Pekanbaru dan begitu juga untuk surat keluar yang dikeluarkan SMP Negeri 32 Pekanbaru dalam satu bulan 10-20 buah surat.

Berdasarkan permasalahan proses administrasi pengarsipan dan pengelolaan surat masuk dan keluar pada SMP Negeri 32 Pekanbaru memerlukan administrasi pengarsipan dan pengelolaan surat masuk dan keluar yang lebih efektif dan efisien yaitu dengan menggunakan sebuah aplikasi pengarsipan surat masuk dan surat keluar. Aplikasi ini nantinya yang akan menjadi basis data penyimpanan data surat masuk dan keluar pada SMP Negeri 32 Pekanbaru, sehingga tidak ada lagi yang namanya pencarian arsip surat dalam tumpukan surat yang banyak dan tidak ada lagi arsip surat yang hilang. 
Aplikasi ini dibangun dengan berbasis web dan tidak di-Onlline-kan dengan menggunakan domain hanya dilingkup SMP Negeri 32 Pekanbaru menggunakan jaringan LAN (Local Area Network), dan untuk aktor yang dapat mengakses aplikasi adalah Admin, bagian Tata Usaha dan Kepala Sekolah. Proses penggunaan aplikasi pengarsipan surat masuk dan keluar ini dimulai dari bagian Tata Usaha dengan meng-scan surat masuk dan surat surat keluar dan menyimpan file arsip surat ke format PDF lalu di Upload ke aplikasi dengan memasukkan data-data surat yang dibutuhkan. Untuk surat masuk ada notifikasi kepada Kepala Sekolah untuk di Disposisi sebelum surat dilanjutkan kepada yang bersangkutan atau sesuai tujuan dari surat tersebut.

Penelitian yang dilakukan oleh peneliti sebelumnya dengan tema dan lingkup pembahasan yang sama menghasilkan sebuah sistem informasi pengarsipan surat yang berbasis web mampu mengarsipkan surat, baik surat maupun surat keluar dan meringankan sistem penelusuaran berkas surat dengan akurat, cepat dan efesien (Suryadi and Zulaikhah, 2019). Penelitian selanjutnya yang juga berkaitan dengan tema penelitian ini diperoleh hasil implementasi aplikasi memudahkan jurusan dalam mengelola pengarsipan surat dan serta sangat membantu dosen dalam melakukan pembuatan surat di pihak akademik jurusan elektronika Universitas Negeri Padang (Farell, Saputra and Novid, 2018).

\section{Metode Penelitian}

Metode penelitian yang diterapkan untuk penelitian ini adalah metode penelitian pengembangan/pembuatan sistem/aplikasi yang disebut dengan sebuah model pengembangan/pembuatan sistem/aplikasi dan model penelitian ini menggunakan/menerapkan model air terjun atau lebih dikenal dengan waterfall model. Model Waterfall ini juga merupakan salah satu dari SDLC (System Development Life Cycle). Model waterfall menurut Sommerville (2011) merupakan tahapan membuat atau mengembangkan suatu perangkat lunak yang dilakukan secara terurut dan model waterfall juga memberikan suatu pendekatan perangkat lunak yang terstruktur dan sekuensial yang diawali dengan mendefinisikan kebutuhan sistem yang dilanjutkan perancangan sistem dan perangkat lunak, kemudian penerapan dan menguji unit dari sistem, langkah berikutnya mengintegrasikan dan menguji sistem secara keseluruhan kepada pengguna, yang dilanjutkan langkah mengoperasikan dan perawatan sistem (Wiyono, Nugroho and Astri, 2019). Berikut gambaran metode pengembangan perangkat lunak model waterfall menurut Sommerville:

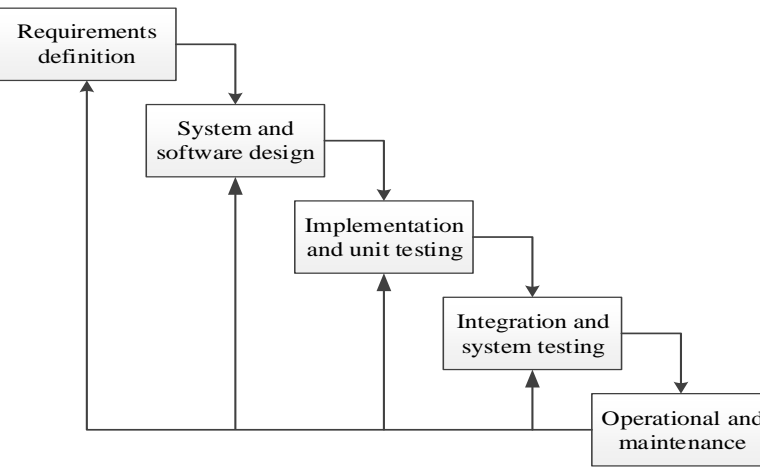

Gambar 1. Model Waterfall

Berikut langkah-langkah pembuatan dan pengembangan aplikasi pengarsipan surat masuk dan surat keluar berbasis web pada SMP Negeri 32 Pekanbaru dengan menerapkan model waterfall yang diawali dari:

a. Requirements definition (Mendefinisikan Persyaratan), proses pada tahapan yang pertama ini, peneliti melakukan beberapa langkah untuk memenuhi persyaratan dalam pembuatan dan mengembangkan aplikasi pengarsipan surat masuk dan surat keluar berbasis web pada SMP Negeri 32 Pekanbaru, berikut langkah-langkah yang peneliti lakukan:

1. Pengamatan langsung (Observasi)

Tahapan observasi ini peneliti langsung datang ke SMP Negeri 32 Pekanbaru dan peneliti mengamati proses sistem surat menyurat yang berlangsung, baik untuk surat masuk sampai ke proses disposisi surat ke kepala sekolah dan dari kepala ke staf guru atau pegawai sekolah laiinya, maupun surat keluar sampai proses pengiriman dengan menggunakan jasa pengiriman. Bagian dari proses observasi ini, peneliti juga meninjau arsip surat yang lama maupun yang beru diarsipkan, dan sekaligus peneliti meninjau buku agenda surat masuk dan keluar.

2. Wawancara (interview)

Tahapan wawancara yang peneliti lakukan merupakan proses diskusi dengan kepala sekolah, bagian tata usaha, staf guru serta pegawai lainnya tentang proses surat masuk dan surat keluar pada SMP Negeri 32 Pekanbaru, proses ini dilakukan untuk mendapatkan keterangan yang lebih lengkap dalam memenuhi persyaratan pembangunan dan pengembangan aplikasi pengarsipan 
surat masuk dan surat keluar berbasis web pada SMP Negeri 32 Pekanbaru.

3. Studi pustaka

Tahapan berikutnya dalam memenuhi persyaratan sistem yakni melakukan studi pustaka. Studi pustaka ini dilakukan untuk memperoleh keterangan dengan lengkap yang berasal dari berbagai buku, artikel jurnal yang berkaitan, dan majalah serta sumber-sumber lainnya seperti browsing di internet yang berkaitan dengan tema penelitian ini. Sumber-sumber ini juga dijadikan sebagai sumber rujukan penulisan laporan penelitian.

b. System and software design (Perancangan sistem dan perangkat lunak), Tahapan ini merupakan kelanjutan dari tahapan sebelumnya yang telah selesai dikerjakan. Tahapan System and software design merupakan proses perancangan sistem dengan menerapkan sebuah bahasa pemodelan (modeling language). Bahasa pemodelan yang digunakan adalah UML (Unified Modeling Language). UML (Unified Modeling Language) merupakan bahasa pemodelan (modeling language) dengan menerapkan pada model perancangan perangkat lunak atau sistem dengan model bahasa mengacu pada objek (berorientasi objek) (Wati and Kusumo, 2016). Proses perancangan UML (Unified Modeling Language) aplikasi pengarsipan surat masuk dan surat keluar berbasis web pada SMP Negeri 32 Pekanbaru dengan mengvisualisasikan ke dalam bentuk model diagram. Model diagram yang divisualisasilkan dalam merancang aplikasi ini diantaranya use case diagram, activity diagram, dan class diagram, berikut pembahasannya :

\section{Use Case Diagram}

Use case diagram merupakan bagian dari UML yang menvisualisasikan aktifitas atau peran Use case dengan pengguna atau aktor. Use case Diagram adalah skema sekumpulan use case dan aktor (pengguna) yang diikuti beserta relasi aktivitas setiap use case dan aktor. Diagram use case dapat mendefinisikan dan mengartikan keperluan yang dimau oleh pengguna, serta sangat bermanfaat untuk menetapkan struktur organisasi dan skema dari perangkat lunak (Maiyana and Mengkasrinal, 2017). Berikut gambaran Use case diagram aplikasi pengarsipan surat masuk dan surat keluar berbasis web pada SMP Negeri 32 Pekanbaru:

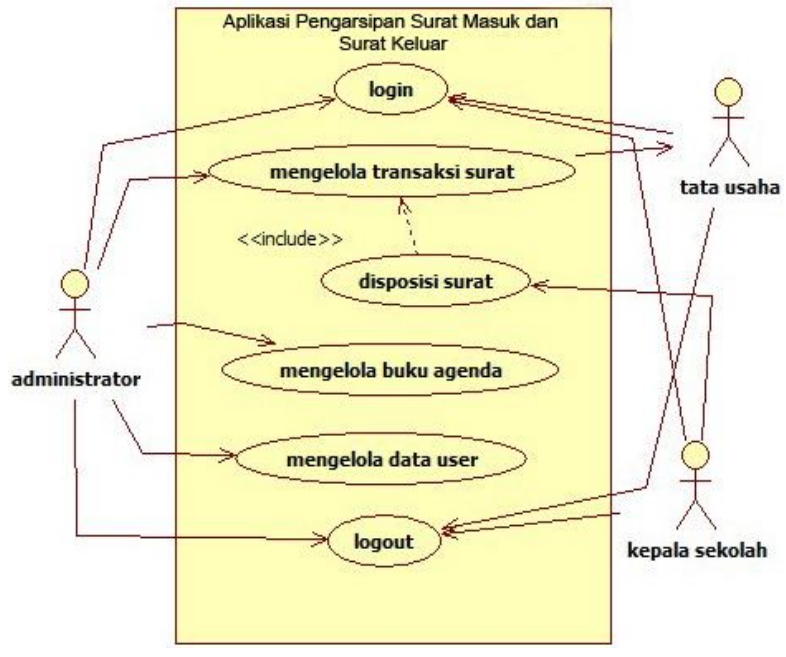

Gambar 2. Use Case Diagram

Diagram use case pada sistem ini menjelaskan aktor yang dapat mengakses secara langsung aplikasi pengarsipan surat masuk dan surat keluar yang terdiri dari 3 (tiga) aktor yaitu administrator, tata usaha dan kepala sekolah yang mempunyai tugas yang berbeda.

2. Activity Diagram

Berikutnya tahapan merancang dan membuat Diagram Aktivitas (Activity Diagram). Activity Diagram merupakan diagram yang menunjukkan aktivitas yang dilakukan user atau pengguna aplikasi pengarsipan surat masuk dan surat keluar. Activity Diagram menjelaskan dan mengilustrasikan rangkaian kerja atau kegiatan dari suatu perangkat lunak/sistem/aplikasi atau prosedur bisnis (Hendini, 2016). Berikut gambaran Activity Diagram aplikasi pengarsipan surat masuk dan surat keluar berbasis web pada SMP Negeri 32 Pekanbaru:

a) Activity Diagram Login

Berikut adalah Diagram aktivitas (Activity diagram) untuk melakukan login yang menjelaskan tentang diagram aktivitas untuk bisa masuk dan mendapatkan akses ke tampilan awal (beranda), diawali dengan aktor memasukkan username dan password untuk login ke aplikasi. Berikut gambaran Activity diagram login ke aplikasi pengarsipan surat masuk dan surat keluar berbasis web pada SMP Negeri 32 Pekanbaru: 


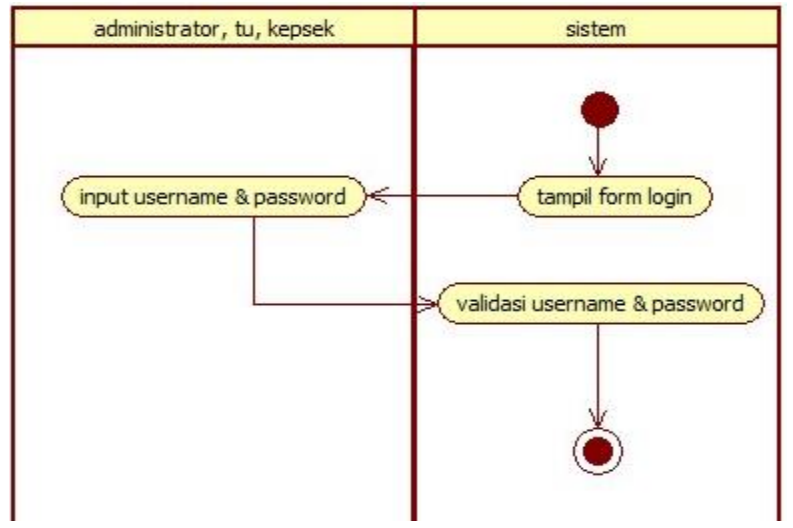

Gambar 3. Activity Diagram Login

b) Activity Diagram Transaksi Surat Masuk dan Disposisi

Activity Diagram ini menjelaskan tentang diagram aktivitas transaksi data surat masuk yang dimasukkan oleh bagian Tata Usaha dan di disposisi surat mausk oleh kepala sekolah pada aplikasi pengarsipan surat masuk dan surat keluar pada SMP Negeri 32 Pekanbaru yang dapat dilihat pada gambar berikut:

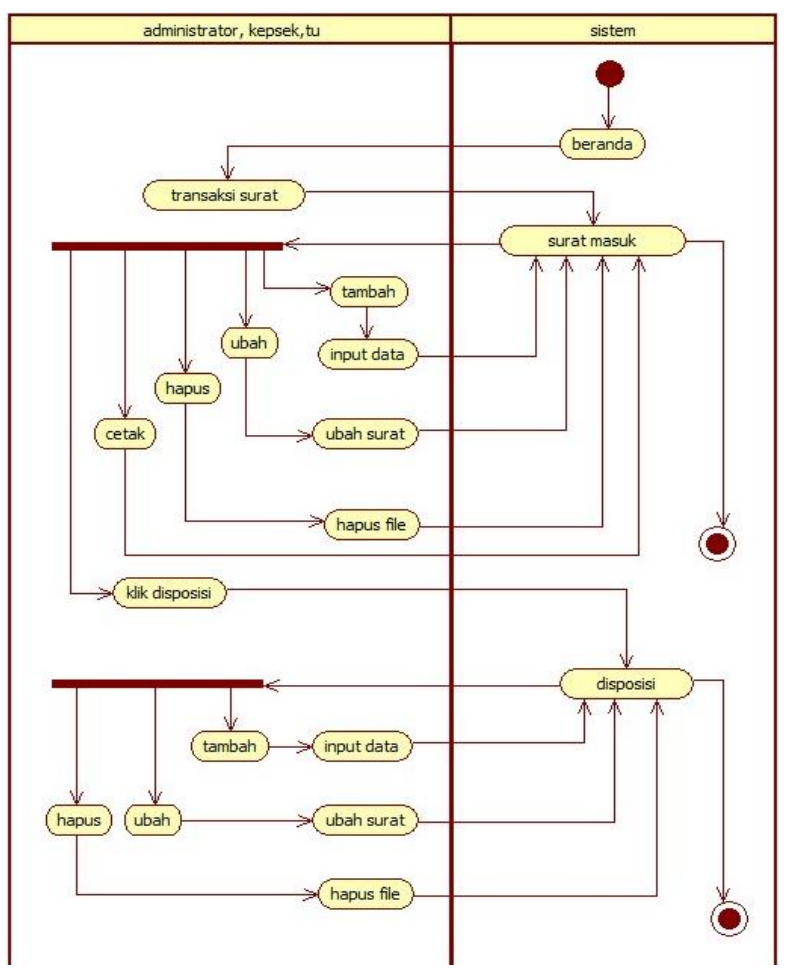

Gambar 3. Activity Diagram Transaksi Surat Masuk dan Disposisi

c) Activity Diagram Transaksi Surat Keluar Gambar 4 berikut menjelaskan tentang diagram aktivitas transaksi surat keluar pada aplikasi pengarsipan surat masuk dan surat keluar berbasis web pada SMP Negeri 32 Pekanbaru:

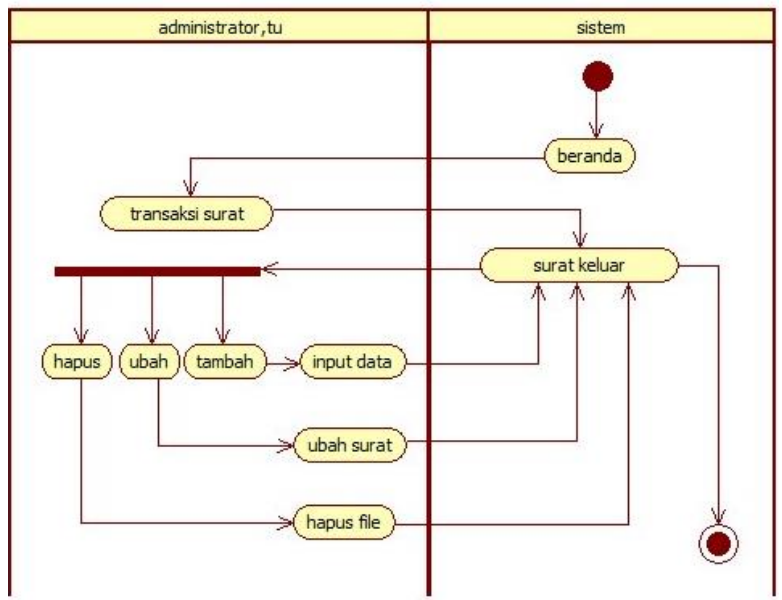

Gambar 4. Activity Diagram Transaksi Surat Keluar

d) Activity Diagram Buku Agenda Activity Diagram berikut menjelaskan tentang diagram aktivitas pembuatan laporan atau buku agenda. Aktor dapat mencetak laporan surat masuk dan surat keluar atau yang disebut dengan buku agenda surat masuk dan surat keluar yang dapat dilihat dibawah ini:

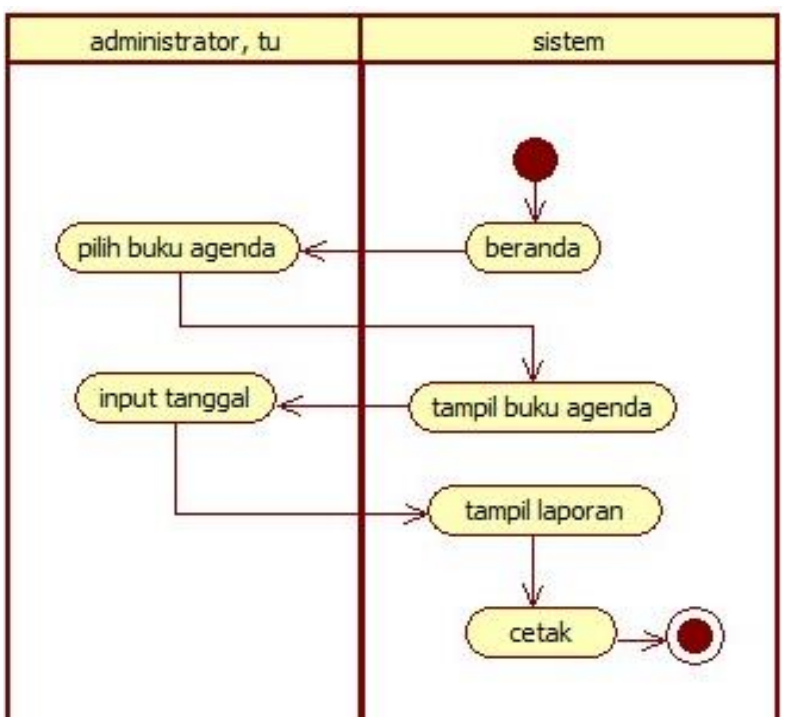

Gambar 5. Activity Diagram Buku Agenda

e) Activity Diagram Administrator

Berikut adalah Diagram Aktivitas (Activity Diagram) Administrator yang mengambarkan dan menjelaskan tentang diagram aktivitas user untuk administrator pada aplikasi pengarsipan 
surat masuk dan surat keluar berbasis web pada SMP Negeri 32 Pekanbaru:

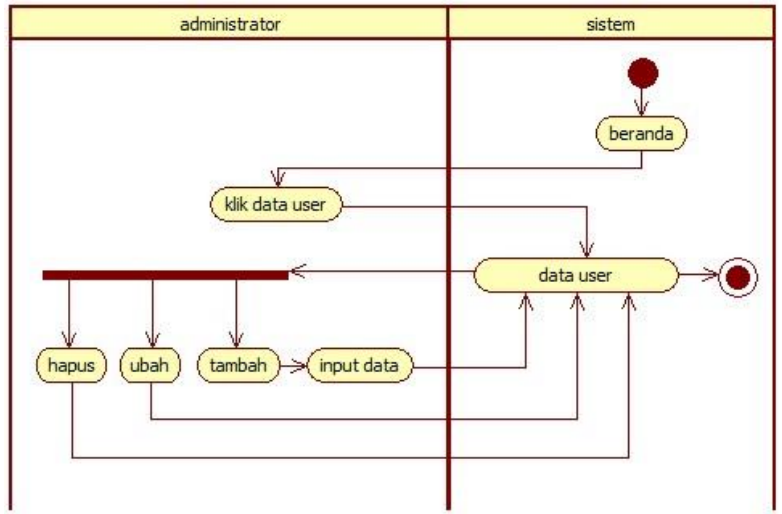

Gambar 6. Activity Diagram Administrator

\section{Class Diagram}

Tahap berikutnya yang tidak kalah penting adalah perancangan dan pembuatan class diagram yang juga merupakan bagian dari UML. Diagram Kelas (Class Diagram) menggambarkan desain kelas yang berada di dalam sistem desain aplikasi yang akan dibangun/dikembangkan, class diagram memiliki relasi antar kelas pada sistem basis data aplikasi yang masih dibuat dan di setiap kelas tersebut saling berkerjasama dan berhubungan untuk memperoleh tujuan akhir yang diharapkan pengguna aplikasi (Puspasari and Chandra, 2018). Class diagram untuk aplikasi aplikasi pengarsipan surat masuk dan surat keluar berbasis web pada SMP Negeri 32 Pekanbaru class user memiliki keterhubungan langsung dengan class surat masuk, class surat keluar, dan class disposisi. class disposisi tidak akan bisa ada tanpa adanya class surat masuk dan surat keluar.

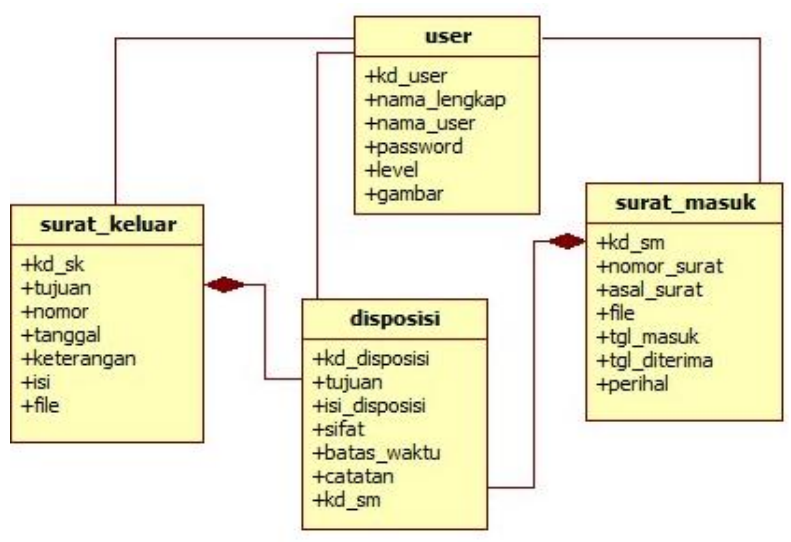

Gambar 7. Class Diagram
4. Basis data (Database)

Tahap berikutnya adalah pembuatan basis data (database) yang merupakan bagian terpenting dari sebuah aplikasi, basis data ini terdiri dari sejumlah tabel yang saling berelasi satu sama lainnya. Perancangan basis data ini juga merupakan bagian dari class diagram. Basis data merupakan gabungan data yang terelasi dan tersimpan di dalam suatu perangkat, yang dikomposisikan secara terstruktur dan terskema dengan perangkat lunak tertentu untuk melaksanakan pengolahan data dengan tujuan tertentu (Pamungkas, 2017). Basis data pada aplikasi terdiri dari Tabel User, Tabel Surat Masuk, Tabel Surat Keluar, dan Tabel Disposisi. Pembuatan basis data menggunakan MySQL dan menurut Rudianto (2011) merupakan bagian basis data server yang terpopuler dan menjadi nomor satu yang dimanfaatkan untuk pembuatan dan mengembangkan suatu aplikasi web yang memanfaatkan basis data sebagai sumber untuk memanipulasi datanya. MySQL melabangkan basis data perdana yang didukung oleh bahasa pemrograman yang script-nya untuk internet ( $P H P$ dan Perl). MySQL lebih banyak diterapkan untuk membangun dan mengembangkan aplikasi berbasis web, kebanyakan pembuatan dan pengembangan perangkat lunak atau aplikasinya menggunakan bahasa pemrograman script PHP (Simangunsong, 2018).

5. Antarmuka aplikasi

Perancangan antarmuka/tampilan aplikasi adalah salah satu komponen yang utama dalam mendesain sebuah aplikasi/perangkat lunak. Dalam prosedur mendesain antarmuka, tentunya tidak bisa lepas dari atau tidak mungkin terpisahkan dari semua prosedur pembuatan/pengembangan suatu aplikasi/perangkat lunak. Prosedur yang dilakukan dalam mendesain antarmuka, dikonsentrasikan terletak pada fitur dan komponen antarmuka yang pemakai tampak dan difungksikan, dibandingkan atas kepasitas suatu program, sebab desain antarmuka berarti untuk menyampaikan sketsa dari aplikasi/perangkat lunak yang hendak dibuat/dikembangkan, maka akan mnyederhanakan dalam penerapan aplikasi/ perangkat lunak. Perancangan antar muka 
yang dibangun untuk aplikasi ini adalah antar muka memasukkan surat masuk dan surat keluar, disposisi surat masuk, laporan surat masuk dan keluar.

c. Implementation and unit testing (Penerapan dan menguji unit)

Tahapan ini dimana aplikasi dibangun dan dikembangkan sesuai dengan pemodelan yang telah dibuat sebelumnya. Pembuatan aplikasi menggunakan bahasa pemrograman PHP menurut Medcoms (2016) merupakan bahasa pemrograman script server-side yang didesain untuk mengembangkan dan membangun aplikasi web dan sebutan lainnya bahasa pemprograman server side, sebab PHP diolah dengan komputer server. PHP (Hypertext Preprocessor) adalah Bahasa sintak (script) yang dapat diterapkan untuk membangun dan mengembangan perangkat lunak atau aplikasi situs web dinamis. Bertolak belakang dengan bahasa pemrograman client-side seperti JavaScript yang diolah dengan web browser (client) (Irawan and Simargolang, 2018).

Selanjutnya pengujian dilakukan setiap unit yang selesai dibangun, dengan menguji setiap fungsi dan modul aplikasi untuk mengetahui keberfungsian setiap unit aplikasi. Setiap selesai pembuatan script bahasa pemrograman PHP dilakukan pengujian terhadap modul dan fungsional aplikasi yang dibangun.

d. Integration and System Testing (Integrasi dan Pengujian Sistem)

Setelah aplikasi selesai dibangun dan unitunit aplikasi telah befungsi dengan baik selanjutnya aplikasi diserahkan kepada pengguna. Penyerahan aplikasi sekaligus mengintegrasikan aplikasi ke dalam sistem pengasipan surat masuk dan keluar pada SMP Negeri 32 Pekanbaru sebagai objek penelitian. Integrasi aplikasi yang dilakukan dengan menerapkan metode migrasi sistem secara paralel, yaitu sistem yang lama masih tetap berjalan dan beriring dengan sistem atau aplikasi baru.

Setelah aplikasi diintegrasikan ke sistem sistem pengasipan surat masuk dan keluar yang sedang berjalan pada SMP Negeri 32 Pekanbaru, masuk ke tahap pengujian sistem secara keseluruhan saat sistem telah berjalan. Pengujian dilakukan dengan metode Black Box Testing. Black Box Testing merupakan mekanisme pengujian aplikasi yang terpusat pada detail fungsional dari suatu aplikasi (Nur et al., 2020).

e. Operational and Maintenance (Pengoperasian dan Pemeliharaan)

Pengoperasian aplikasi bekerja dengan baik dan berjalan seiring dengan sistem surat masuk dan keluar yang lama. Perangkat pendukung aplikasi juga bekerja dengan baik, seperti mencetak laporan surat masuk dan keluar di print dan koneksi aplikasi ke komputer kepala sekolah, humas dan guru berjalan dengan baik karena dari penilaian secara keseluruhan terhadap aplikasi dengan nilai $96 \%$ bahwa aplikasi sangat membantu pengarsipan surat masuk dan keluar pada SMP Negeri 32 Pekanbaru serta aplikasi bekerja sangat efektif dan efisien.

Seiring berjalannya aplikasi tentunya tidak lepas dari yang namanya pemeliharaan. Pemeliharaan aplikasi dilakukan jika ada fungsi dan modul tidak berfungsi dan akan dilakukan perbaikan secara langsung, karena admin (tata usaha) juga paham tentang pemrograman web. Pengembangan aplikasi tentunya akan dilakukan sesuai dengan kebijakan dan kebutuhan manajemen SMP Negeri 32 Pekanbaru dan juga tututan perkembangan teknologi informasi. Proses pengembangan tentunya akan memakan waktu yang lama, karena pengembangan suatu aplikasi tidak akan pernah selesai, hal ini disebabkan pengembangan aplikasi selalu mengutamakan keinginan pemakai aplikasi yang semakin bertumbuh seiring dengan perkembangan zaman dan teknologi dari masa ke masa.

\section{Hasil dan Pembahasan}

Tahapan ini adalah tampilan dari aplikasi yang telah selesai dibangun dan tahap ini sangat bergantung pada metode penelitian yang di implementasikan pada model. Model yang terapkan dalam pembuatan aplikasi pengarsipan surat masuk dan keluar pada SMP Negeri 32 Pekanbaru berbasis web ini adalah model air terjun (Waterfall). Berdasarkan model waterfall tersebutlah peneliti mengikuti langkah-langkah merancang dan membangun aplikasi. Berikut tampilan dari aplikasi yang telah selesai dibangun:

a. Tampilan login

Tampilan berikut form login ketika aplikasi pengarsipan surat masuk dan surat keluar dijalankan. Pada form ini user diwajibkan mengetik username dan password yang sudah 
terdaftar di basis data aplikasi pengarsipan surat masuk dan surat keluar pada SMP Negeri 32 Pekanbaru.

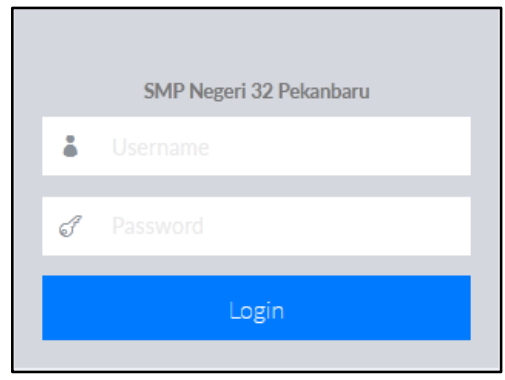

Gambar 8. Tampilan Login

b. Tampilan Beranda Admin

Tampilan beranda admin aplikasi pengarsipan surat masuk dan surat keluar pada SMP Negeri 32 Pekanbaru terdapat informasi berupa jumlah surat masuk, jumlah surat keluar, dan jumlah data user, seperti terlihat pada gambar 9 berikut ini:

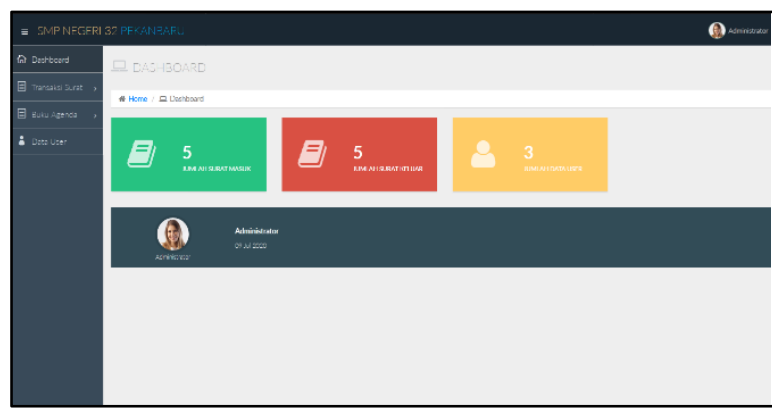

Gambar 9. Tampilan Beranda Admin

Dari tampilan beranda dari admin terlihat hampir semua menu aplikasi dapat diakses oleh admin. Salah satu tugas dari admin aplikasi adalah penambahan dan menonaktifkan user, berikut dibawah ini adalah tampilan untuk menambah user pada aplikasi:

1) Tampilan Untuk Menambah User

Berikut tampilan untuk menambah user pada aplikasi pengarsipan surat masuk dan surat keluar pada SMP Negeri 32 Pekanbaru dan semua data yang diminta wajib di isi agar dalam proses penambahan user tidak ada kendala.

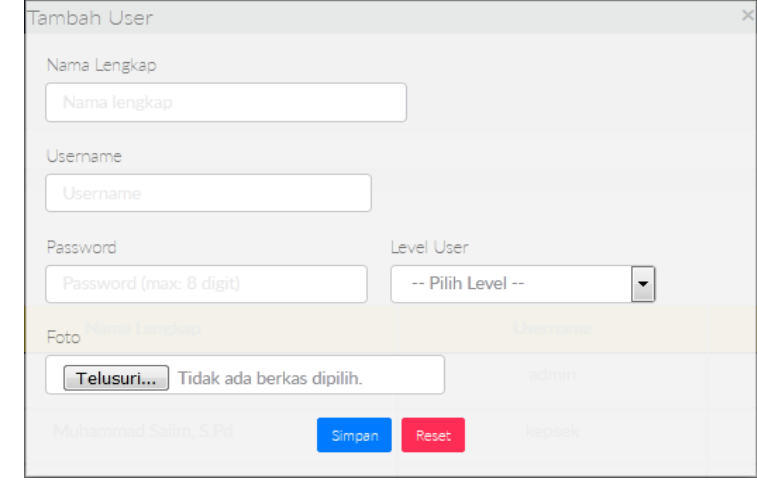

Gambar 10. Tampilan Untuk Menambah User

2) Tampilan Untuk Mengubah Data User

Di bawah ini adalah tampilan untuk mengubah data user aplikasi pengarsipan surat masuk dan surat keluar pada SMP Negeri 32 Pekanbaru. Untuk mengubah data user bisa dilakukan oleh admin secara langsung.

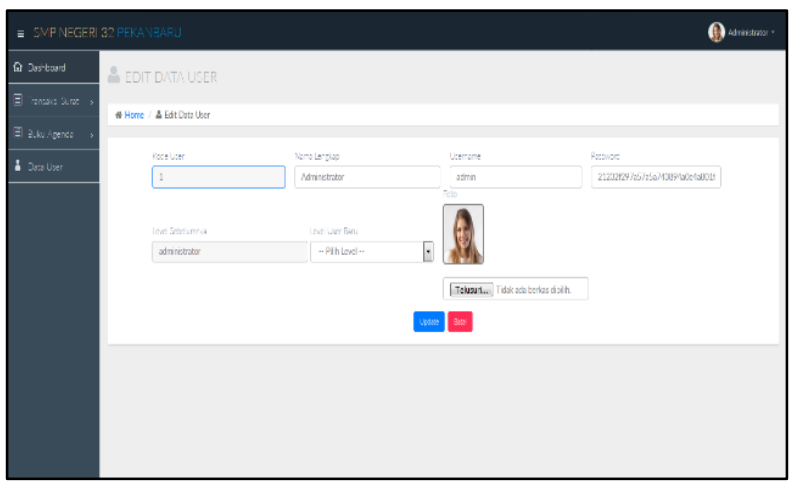

Gambar 11. Tampilan Untuk Mengubah Data User

3) Tampilan Data User

Pada tampilan berikut ini adalah tampilan data user yang telah dimasukkan/ ditambahkan pada aplikasi pengarsipan surat masuk dan surat keluar pada SMP Negeri 32 Pekanbaru. Pada aplikasi ini secara umum ada tiga user yang bisa menggunakan aplikasi ini. 


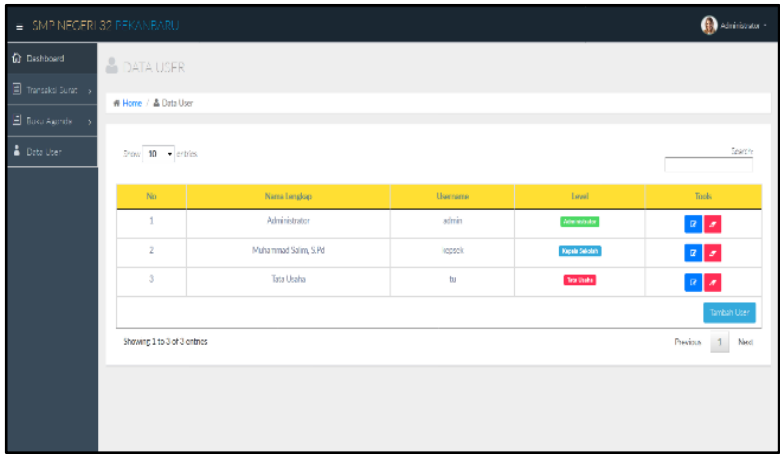

Gambar 12. Tampilan Daftar User

c. Tampilan Beranda Tata Usaha

Berikut adalah Tampilan beranda tata usaha di aplikasi pengarsipan surat masuk dan surat keluar pada SMP Negeri 32 Pekanbaru. Pada beranda Tata Usaha terdapat informasi yang ditampilkan berupa jumlah surat masuk, jumlah surat keluar, dan jumlah data user.

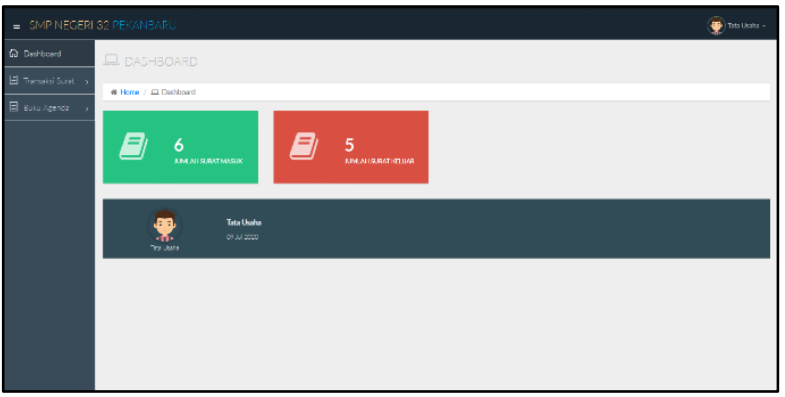

Gambar 13. Tampilan Beranda Tata Usaha

Dari beranda ini tata usaha bisa melakukan transaksi menambahkan surat masuk dan surat keluar berikut tampilan transaksi menambahkan surat masuk:

1) Tampilan Transaksi Menambahkan Surat Masuk

Tampilan berikut adalah transaksi menambahkan surat masuk pada aplikasi pengarsipan surat masuk dan surat keluar pada SMP Negeri 32 Pekanbaru. Pada tempilan ini terdiri beberapa data yang wajib diisi oleh bagian Tata Usaha.

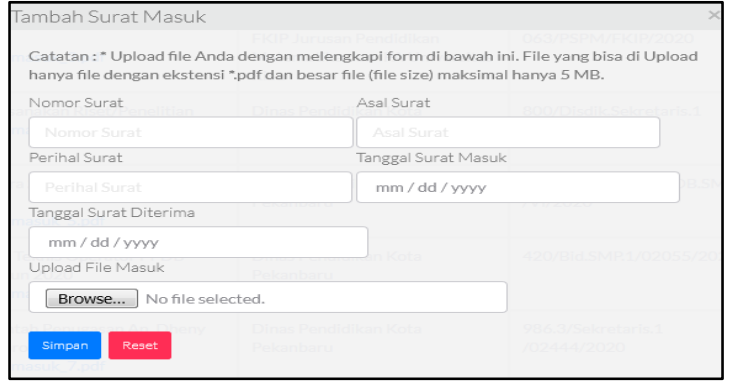

Gambar 14. Tampilan Transaksi Menambahkan Surat Masuk

2) Tampilan Transaksi Menambahkan Surat Keluar

Dibawah ini adalah tampilan transaksi menambahkan surat keluar pada aplikasi pengarsipan surat masuk dan surat keluar pada SMP Negeri 32 Pekanbaru. Untuk tampilan penambahan surat keluar ini ada beberapa data yang wajib diisi.

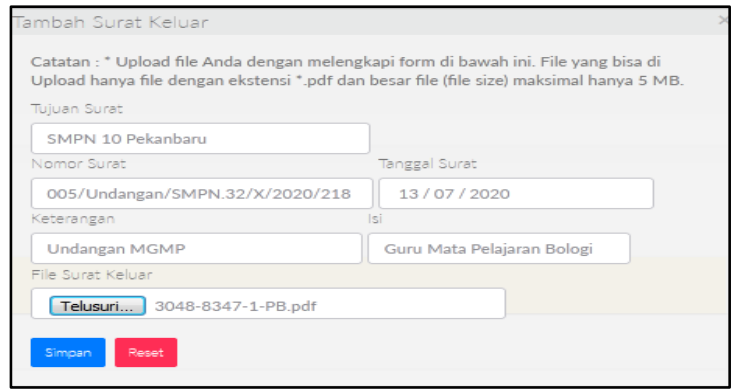

Gambar 15. Tampilan Transaksi Menambahkan Surat Keluar

3) Tampilan Mengubah Transaksi Surat Masuk Berikut tampilan untuk mengubah surat masuk pada aplikasi pengarsipan surat masuk dan surat keluar pada SMP Negeri 32 Pekanbaru. Mengubah surat masuk ini dilakukan jika ada kesalahan ketika memasukkan/mengisi data surat masuk.

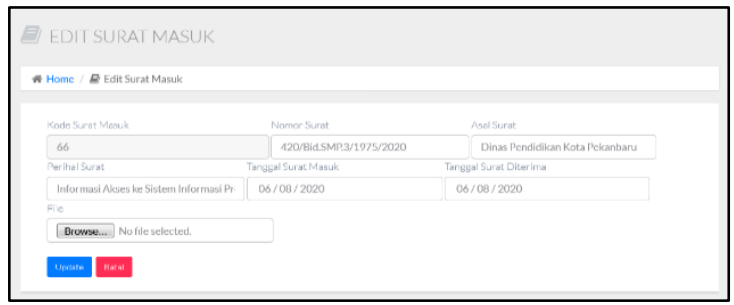

Gambar 16. Tampilan Mengubah Transaksi Surat Masuk 
4) Tampilan Mengubah Transaksi Surat Keluar Gambar 17 berikut adalah tampilan untuk mengubah surat keluar pada aplikasi pengarsipan surat masuk dan surat keluar pada SMP Negeri 32 Pekanbaru. Mengubah surat keluar ini dilakukan jika ada kesalahan ketika memasukkan/mengisi data surat keluar oleh bagian Tata Usaha.

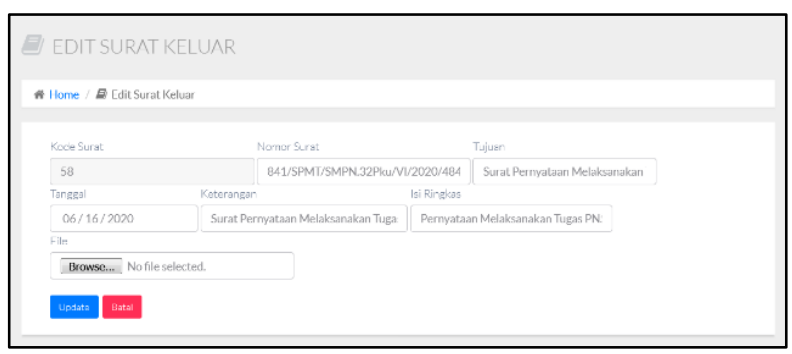

Gambar 17. Tampilan Mengubah Transaksi Surat Keluar

5) Tampilan Data Surat Masuk

Setelah dimasukkan data surat masuk pada aplikasi pengarsipan surat masuk dan surat keluar pada SMP Negeri 32 Pekanbaru. Untuk melihat daftar data surat masuk tersebut tentunya ada tampilan data surat masuk yang terlihat pada gambar berikut:

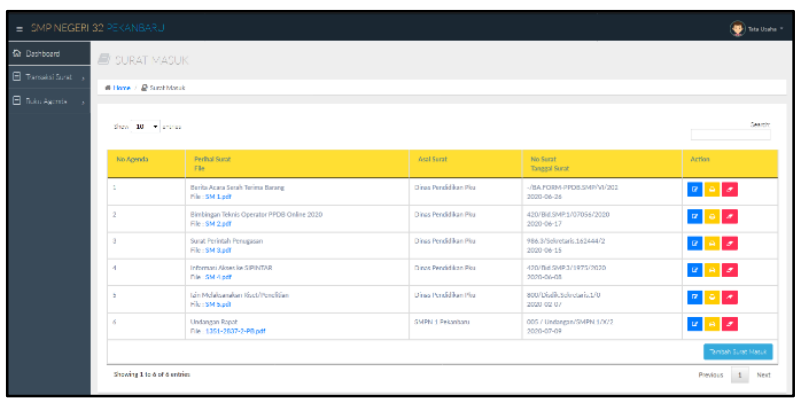

Gambar 18. Tampilan Data Surat Masuk

6) Tampilan Data Surat Keluar

Selanjutnya adalah tampilan data surat keluar yang telah dimasukkan pada aplikasi pengarsipan surat masuk dan surat keluar pada SMP Negeri 32 Pekanbaru. Untuk melihat daftar data surat keluar yang telah dimasukkan tentunya dibutuhkan suatu tabel seperti gambar berikut ini:

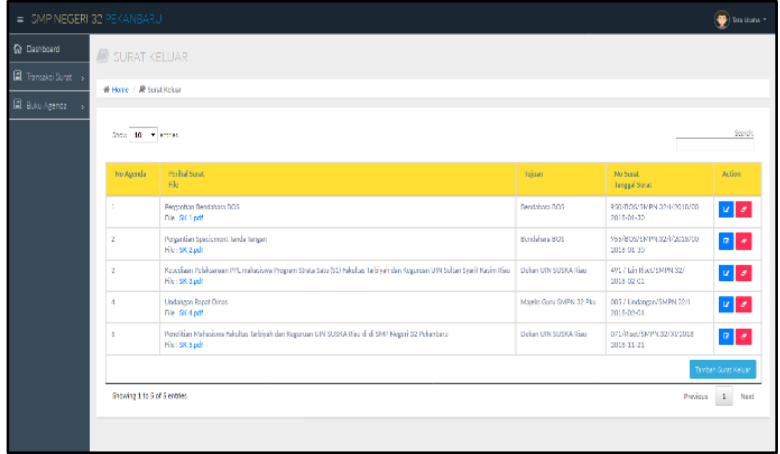

Gambar 19. Tampilan Data Surat Keluar

d. Tampilan Beranda Kepala Sekolah

Pada tampilan beranda kepala sekolah di aplikasi pengarsipan surat masuk dan surat keluar pada SMP Negeri 32 Pekanbaru terdapat beberapa informasi dan menu yang dapat diakses oleh kepala sekolah terutama menu disposisi surat, daftar surat masuk dan keluar, berikut tampilan beranda Kepala Sekolah:

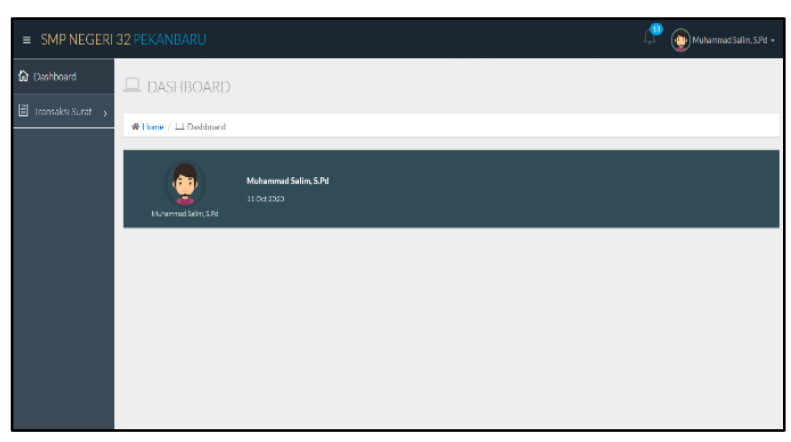

Gambar 20. Tampilan Beranda Kepala Sekolah

Berdasarkan tampilan beranda Kepala Sekolah tersebut ada beberapa aktivitas yang dapat dilakukan oleh Kepala Sekolah seperti berikut:

1) Tampilan Disposisi Surat Masuk

Disposisi surat masuk dapat diketahui kepala sekolah ketika sudah login ke akunnya di aplikasi pengarsipan surat masuk dan surat keluar pada SMP Negeri 32 Pekanbaru, untuk melakukan disposisi kepala sekolah mengklik notofiksi, dan setelah kepala sekolah mengklik notifikasi maka tampil daftar surat masuk yang akan disposisi kepala sekolah. 


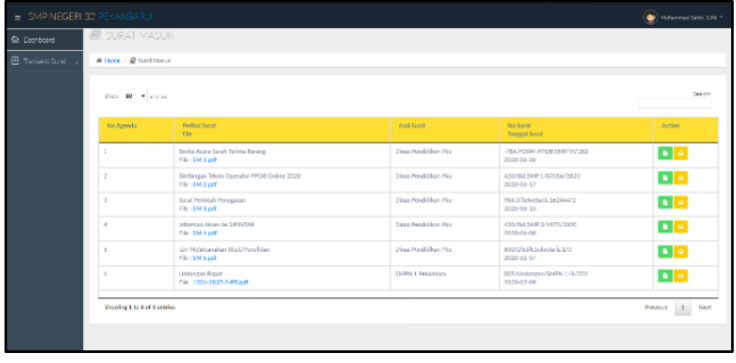

Gambar 21. Tampilan Surat Masuk Yang Akan Disposisi

2) Tampilan Menambah Disposisi

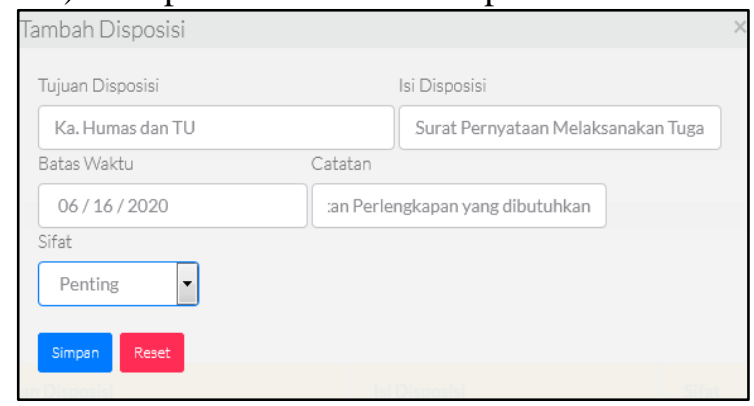

Gambar 22. Tampilan Menambah/Melakukan Disposisi Oleh Kepala Sekolah

3) Tampilan Mengubah Disposisi

Tampilan ini bermaksud untuk mengubah disposisi yang dilakukan oleh kepala sekolah pada aplikasi pengarsipan surat masuk dan surat keluar pada SMP Negeri 32 Pekanbaru. Mengubah diposisi ini dilakukan jika ada terjadi kesalahan ketika melakukan disposisi yang pertama, untuk mengubah ini bisa dilakukan oleh aktor Kepala Sekolah langsung (seharusnya) dan bisa juga aktor bagian Tata Usaha jika diberi izin aktor Kepala Sekolah, berikut tampilan

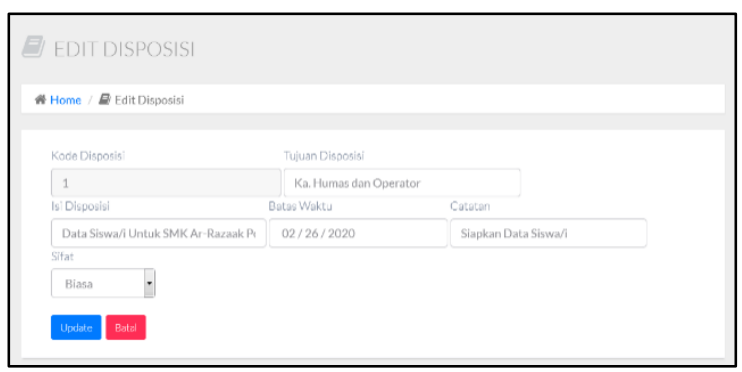

Gambar 23. Tampilan Mengubah Disposisi

\section{c. Tampilan Laporan}

Laporan merupakan hasil dari data pengarsipan surat masuk dan keluar yang telah dimasukkan berbentuk cetak, ada beberapa bentuk laporan/daftar surat masuk dan keluar pada aplikasi pengarsipan surat masuk dan keluar pada SMP Negeri 32 Pekanbaru, Berikut tampilan laporan tersebut:

1) Tampilan Laporan Agenda Surat Masuk Berikut adalah tampilan laporan agenda surat masuk pada aplikasi pengarsipan surat masuk dan surat keluar pada SMP Negeri 32 Pekanbaru. Laporan agenda surat masuk adalah surat yang berasal dari luar/pihak eksternal untuk pihak internal SMP Negeri 32 Pekanbaru.

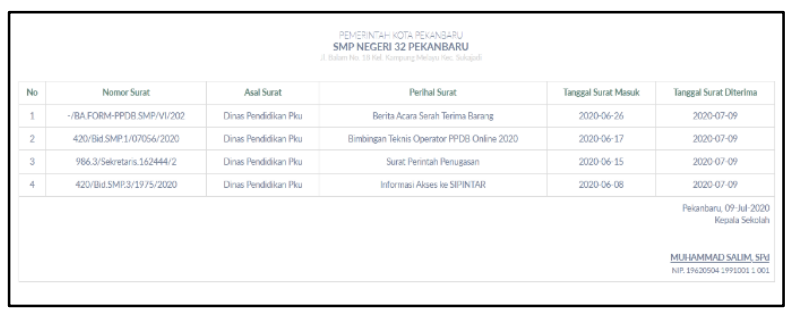

Gambar 24. Tampilan Laporan Agenda Surat Masuk

2) Tampilan Laporan Agenda Surat Keluar Tampilan berikut adalah Laporan agenda surat keluar di aplikasi pengarsipan surat masuk dan surat keluar pada SMP Negeri 32 Pekanbaru. Laporan agenda surat masuk adalah surat yang dikeluarkan oleh SMP Negeri 32 Pekanbaru untuk pihak eksternal.

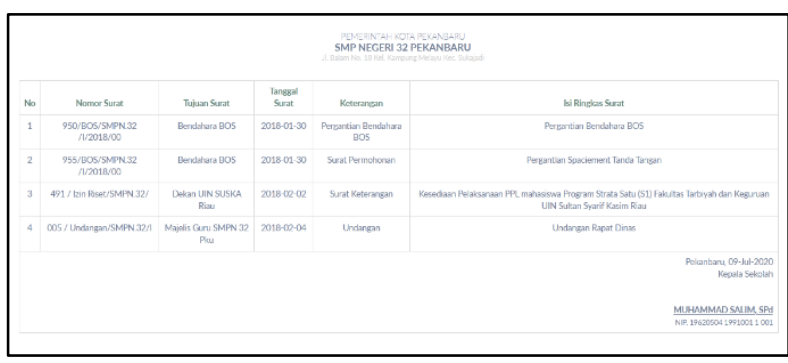

Gambar 25. Tampilan Laporan Agenda Surat Keluar

3) Tampilan Laporan/Cetak Disposisi Surat Masuk

Laporan/cetak disposisi surat masuk ini untuk mengetahui tujuan, maksud dan siapa pelaksana isi dari surat masuk secara spesifik, berikut tampilan laporan/cetak disposisi surat masuk: 


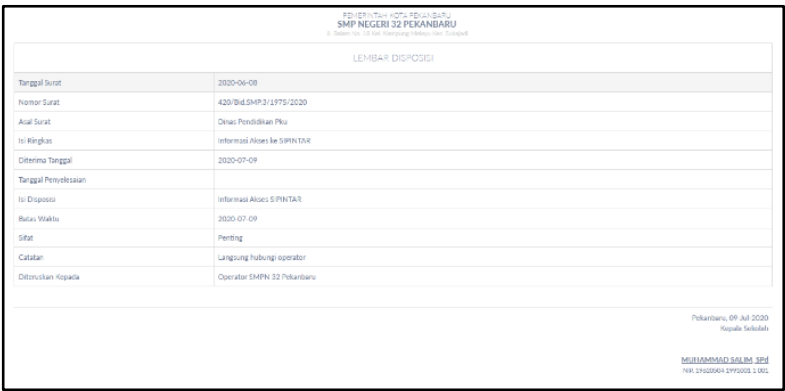

Gambar 26. Tampilan Laporan/Cetak Disposisi Surat Masuk

\section{Kesimpulan}

Berdasarkan pendahuluan, metode peneltian hasil dan pembahasan di atas, bahwa aplikasi pengarsipan surat masuk dan surat keluar pada SMP Negeri 32 Pekanbaru berbasis web diperoleh kesimpulan bahwa aplikasi telah berhasil dirancang dan bangun serta diterapkan dalam aktivitas surat masuk dan surat keluar pada SMP Negeri 32 Pekanbaru. Aplikasi pengarsipan surat masuk dan surat keluar pada SMP Negeri 32 Pekanbaru menjadi lebih terbasis data sehingga pengarsipan menjadi lebih tertata dan dengan adanya aplikasi pengarsipan surat masuk dan keluar ini sangat membantu dan mempermudah SMP Negeri 32 Pekanbaru dalam pengarsipan surat masuk dan keluar, terutama bagian Tata Usaha (Administrasi Sekolah) serta aplikasi juga dinilai oleh kepala sekolah, Ka Humas, serta beberapa orang guru tentang keefektifan dan keefesien aplikasi dengan nilai $92 \%$.

\section{Referensi}

Budiman, H. (2017) 'Peran Teknologi Informasi Dan Komunikasi Dalam Pendidikan', Al-Tadzkiyyah: Jurnal Pendidikan Islam, 8(1), pp. 31-43. doi: 10.24042/atjpi.v8i1.2095.

Farell, G., Saputra, H. K. and Novid, I. (2018) 'Rancang Bangun Sistem Informasi Pengarsipan Surat Menyurat (Studi Kasus Fakultas Teknik Unp)', Jurnal Teknologi Informasi dan Pendidikan (JTIP), 11(2), pp. 56-62. doi: 10.24036/tip.v11i2.142.

Hendini, A. (2016) 'Pemodelan UML Sistem Informasi Monitoring Penjualan dan Stok Barang (Studi Kasus: Distro Zhezha Pontianak)', Jurnal Khatulistiwa Informatika, 6(2), pp. 107-116. doi: 10.31294/jki.v4i2.1262.

Irawan, M. D. and Simargolang, S. A. (2018) 'Implementasi E-Arsip Pada Program Studi Teknik Informatika', JURTI (Jurnal Teknologi Informasi), 2(1).

Maiyana, E. and Mengkasrinal, T. (2017) 'Pengembangan Sistem Informasi Surat
Keterangan Pendamping Ijazah Berbasis Web dan Mobile Android', in Prosiding SISFOTEK 2017, pp. 7-16. Available at: http://seminar.iaii.or.id/index.php/SISFOTEK/ar ticle/view/10.

Masykur, F. and Atmaja, I. M. P. (2015) 'Sistem Administrasi Pengelolaan Arsip Surat Masuk Dan Surat Keluar Berbasis Web', Indonesian Journal on Networking and Security, 4(3), pp. 17. doi: 10.1123/ijns.v4i3.1336.

Nur, H. et al. (2020) 'Pengujian Black Box pada Aplikasi Sistem Pengarsipan Surat Menggunakan Teknik Equivalence Partitions', Jurnal Teknologi Sistem Informasi dan Aplikasi, 3(2), pp. 76-81. doi: 10.32493/jtsi.v3i2.4692.

Pamungkas, C. A. (2017) Pengantar dan Implementasi Basis Data. Yogyakarta: Deepublish.

Prawono, J. and Pamungkas, A. (2015) 'Sistem Informasi Pengelolaan Surat Masuk Dan Surat Keluar Di STMIK AUB Surakarta', Informatika, 2(1), pp. 26-33. Available at: https://ejournal.stie-

aub.ac.id/index.php/informatika/article/view/15 9.

Puspasari, L. and Chandra, W. (2018) 'Aplikasi Pengolahan Data Surat Masuk dan Surat Keluar pada Bagian Kepegawaian Kecamatan Jakabaring Palembang', in Prosiding SEMHAVOK 2018. Palembang: Universitas Bina Darma Palembang, pp. 164-172. Available at: http://conference.binadarma.ac.id/index.php/sem havok/article/view/1302.

Rahman, M. (2017) Ilmu Administrasi. Edited by Sobirin. Makassar: Sah Media.

Sharipuddin and Yani, A. (2018) 'Analisis Dan Perancangan Sistem Informasi Pengelolaan Surat Pada STIKOM Dinamika Bangsa Jambi', Jurnal Ilmiah Media Sisfo, 12(2), pp. 1076-1085. Available at: http://ejournal.stikomdb.ac.id/index.php/mediasisfo/article/view/355.

Simangunsong, A. (2018) 'Sistem Informasi Pengarsipan Dokumen Berbasis Web', Jurnal Mantik Penusa, 2(1), pp. 11-19.

Sommerville, I. (2011) Software Engineering. 9th editio. Massachusetts: Pearson Education.

Suryadi, A. and Zulaikhah, Y. S. (2019) 'Rancang Bangun Sistem Pengelolaan Arsip Surat Berbasis Web Menggunakan Metode Waterfall (Studi Kasus: Kantor Desa Karangrau Banyumas)', Jurnal Khatulistiwa Informatika, 7(1), pp. 13-21. doi: 10.31294/jki.v7i1.36.

Wati, E. F. and Kusumo, A. A. (2016) 'Penerapan Metode Unified Modeling Language (UML) Berbasis Desktop Pada Sistem Pengolahan Kas Kecil Studi Kasus Pada PT Indo Mada Yasa Tangerang', Syntax Jurnal Informatika, 5(1), pp. 24-36. doi: 10.35706/syji.v5i1.699.

Wiyono, T., Nugroho, A. and Astri, L. Y. (2019) 'Perancangan Aplikasi Pengarsipan dan 
Pendaftaran Pertanahan pada Seksi Hubungan Hukum', 1(4), pp. 293-304. Available at: http://ejournal.stikom-

db.ac.id/index.php/jimti/article/view/752/576. 